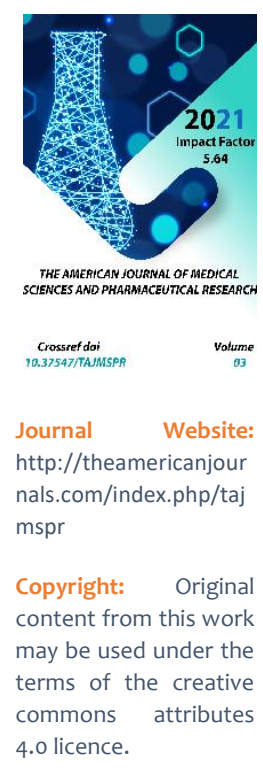

\title{
National Processes In Uzbekistan And The Formation Of The Internationalist Maturity Of The Younger Generation
}

\author{
Soatboy Yuldashev \\ Associate Professor, Head Of The Department, Department Of Pharmacology, Samarkand \\ State Medical Institute, Samarkand, Uzbekistan \\ Yusup Halimbetov \\ Associate Professor, Department Of Humanities And Socio-Economic Sciences, Samarkand \\ State Medical Institute, Samarkand, Uzbekistan \\ Marhabo Usmanova \\ Assistant, Department Of Pharmacology, Samarkand State Medical Institute, Samarkand, \\ Uzbekistan \\ Naimova Z.S \\ Assistant Of Samarkand State Medical Institute, Samarkand, Uzbekistan \\ Khamraeva M \\ Master's Degree From Samarkand State Medical Institute, Uzbekistan
}

\section{ABSTRACT}

The future of our nation is directly linked to the confidence of our young people in the future, their professionalism, knowledge and qualifications. Creating a fundamentally new ideological and political situation in the Republic of Uzbekistan, the Development Strategy has placed the creative activity of all representatives of young people and each individual at the center of the renewal of the Uzbek state. One of them is the level of national self-consciousness, national pride, patriotism, a sense of pride for their homeland and their people, which becomes the meaning, the way of life of citizens, and these qualities reach a fairly high level, including the formation of the internationalist maturity of the younger generation; second, the state manifests itself as a powerful body that determines the main directions of the domestic and foreign policy of society, a conscious managerial mechanism for the transition from a strong state to a just society that implements the requirements and desires of the nation.

\section{KEYWORDS}

National mentality, youth, internationalist maturity, education. 


\section{INTRODUCTION}

A strategy aimed at formally revealing the humanistic nature and creative power of Uzbekistan is impossible without the development of democracy and transparency, self-government of the people, radical economic reform, moral purification of society, and the identification and development of creative opportunities for young people. Creating a fundamentally new ideological and political situation in the Republic of Uzbekistan, the Development Strategy has placed the creative activity of all representatives of young people and each individual at the center of the renewal of the Uzbek state. The unequal experience gained and the extraordinary level of democratization in the past, the tendency and widening gap in socio-economic development in the present, the difficulties of acceleration and the strategy of development in the future-all this inevitably manifests itself and will affect the factors, pace, mechanisms and nature of national processes.

Now, more than ever, it is necessary to understand and be prepared not only for the fact that new problems will arise in the national sphere, but also for the fact that these problems will be different in different regions of the country, some in Kyrgyzstan and quite others in the republics of Central Asia, as in the areas where the peoples of Afghanistan live.

The first President, I. A. Karimov, is absolutely right, because the peculiar national mentality of the Uzbek people was not formed from scratch. Our national traditions and customs have developed over thousands of years, having undergone serious life trials [3].

In turn, the program guidelines of the President of the Republic of Uzbekistan Sh. M.
Mirziyoyev for further democratization of the political life of young people, for expanding the scope of their participation in the management of the affairs of society and the state, stimulate the political development of the individual, the growth of his political consciousness, commitment to the ideals of the future, the ability to implement the policy of the President.

One of them is the level of national selfawareness of national pride, patriotism, a sense of pride for their homeland and their people, which becomes the meaning, the way of life of citizens, and these qualities reach a sufficiently high level; the second-the state manifests itself as a powerful body that determines the main directions of domestic and foreign policy of society, a conscious managerial mechanism for the transition from a strong state to a just society, implementing the requirements and desires of the nation.

During the years of Independence, our country has undergone cardinal evolutionary changes in all spheres of public life. Therefore, immediately after the announcement of the "Declaration of Sovereignty" at the 2nd session of the Supreme Council of Uzbekistan on June 20,1990, at the Extraordinary Session of the XII convocation of the Supreme Council on August 31, 1991, Uzbekistan was declared an independent Republic. On December 29, 1991, the broad masses of the people of independent Uzbekistan, on an alternative basis, guided by democratic principles, for the first time in the history of Independent Uzbekistan, elect the President of the country. Having adopted the National Flag on November 18, 1991, the President of the Republic of Uzbekistan on March 2, 1992 delivers a speech on behalf of the Independent State of Uzbekistan from the rostrum of the United Nations and sets the flag of the country on a par with the flags of 
the Member States of the United Nations. This historic date has a worldwide significance in the history of a multinational working people.

The following years, one after another, the state symbols of the Republic of Uzbekistan were adopted at the session of the Supreme Council on June 2, 1992 - the State Emblem, December 10, 1992 - the National Anthem, at the $\mathrm{XI}$ session of the Supreme Council on December 8, 19992 - the Constitution of Independent Uzbekistan.

Real national processes are manifested; as a) intra-national, b) inter-ethnic (as inter-ethnic relations and inter-ethnic communication); c) international (between the peoples of different countries; between the peoples of neighboring states). National processes in different peoples, in different states, do not occur in the same way and are not uniform $[16,19,20]$.

Scientific approach to national processes, on the one hand, requires their knowledge, understanding, research, on the otherconscious impact on them as a whole, requires the solution of both contradictory objective nature, and overcoming difficulties (and even mistakes and missteps) generated by actions of a subjective order.

More than a hundred years ago, more than 70 representatives of the nation and nationalities lived in today's Uzbekistan, and in 1926 90, in 1956 113, in 1979 123, in 1989 130, in 2018 reached 136 representatives and nationalities.

In our country, in the 80-90s, a lot of efforts were made to develop the theory of international education, including the issues of forming the internationalist maturity of the younger generation.
A significant part of the works of specialists is devoted to the theoretical and methodological problems of internationalist education.

The attitude of our people to life, society, and natural conditions over the course of thousands of years has endowed them with creativity, charity, judgment, and calmness. Even in the most acute and decisive moments, he was distinguished by a reasonable and delicate attitude to his elders, respectful to his juniors, and courtesy, which influenced the formation and improvement of his mentality.

Together, they can make their contribution to the development of theoretical problems of internationalist education, in particular, to reveal internationalist education as a category of spiritual and moral worldview; to clarify the main goal of internationalist education and the main directions of its implementation; to justify the formation of internationalist maturity as a pattern of formation and development of national social communities and a fundamentally new community of people of an independent and just type; to reveal the content of the categoryinternationalist maturity; to explain the " mechanism" of a scientifically-based system for the formation of internationalist maturity and a number of other issues - this is the purpose of the article under review.

There is still a lack of scientifically based recommendations on a number of pedagogical, psychological, organizational and managerial problems of internationalist education of various categories of young people.

The scientific theory of the formation of internationalist maturity sets many other fundamental requirements for teachers of schools, preschool institutions and higher 
education, in addition to the above-mentioned ones. Among them: deep knowledge of the scientific and theoretical rules of the nation, national processes, internationalism, nationalism, the principles of indigenous national policy; objective knowledge of the object of education, in our case, students and working youth and their various groups (taking into account the level of their social, including the level of internationalist maturity, knowledge, skills, abilities, taking into account their psychological characteristics), the presence in each team of a scientifically based system of internationalist education, taking into account all its main directions, but above all the formation of internationalist consciousness and the involvement of each young person (taking into account a differentiated approach) in active internationalist activities of the fundamental principles, a complete set of means, forms and main methods of educational influence; clear coordination of educational activities not only in the educational institution, but also at the level of all sites, institutions, institutions, organizations that influence the formation of an internationalist-patriot; the presence and constant maintenance in each team of a healthy, effective, uplifting atmosphere (labor, moral, legal, aesthetic, organizational).

The implementation of the requirements of an integrated approach to the education of a new person is closely related to the implementation of the strategic guidelines of President Sh.M. Mirziyoyev - further raising the material and cultural standard of living of young people on the basis of dynamic and proportional development of social production, increasing its efficiency, accelerating modernization, increasing labor productivity, and improving the quality of work in all parts of the national economy.
The integrated approach, put forward by practice, is now raised to the level of all state activities. The theoretical and practical significance of the analysis of the integrated approach in the organization of internationalist work is that the implementation of its requirements allows the country's leadership to ensure a higher level of propaganda and agitation, to strengthen their efficiency and concreteness, connection with life, with the solution of economic and political tasks, to develop offensive, combative in educational work, understanding of the need to resolutely fight against people alien influences and remnants of the past, with all that hinders our movement forward. The very process of educating Sh. $M$. Mirziyoyev considered it as a complex system of interconnected and complementary types, directions and means of educational activity, united by one goal - the formation of a comprehensively and hormonally developed new young person of the new Uzbekistan [7].

The improvement of the internationalist education of the youth of Uzbekistan is not a temporary phenomenon, characteristic only for a certain period, but a constant trend for the activities of all the leaders of the new Uzbekistan.

What is a comprehensive approach to the systematic implementation of the tasks of internationalist educational work? First and foremost, it means taking into account and consciously implementing both the totality of the interrelationships between the various directions, forms and methods of this work, and its interaction with other processes. In this regard, the integrated approach can be considered as a method of organizing practical actions. It requires an approach to education as an integral system in which technical and economic, economic and organizational factors interact, theoretical 
activities and practical experience, politics and ideology, the object and subject of education, social relations between young people, their living conditions and everyday life are taken into account.

An integrated approach means that in the process of education we are talking about the formation of not one or several, but the whole complex of qualities in their unity and interaction. It covers the whole range of educational activities. The integrated approach most fully reflects the diversity of educational work, the dialectic of the process of internationalist education $[6,10,11]$.

Internationalist education largely determines the formation and development of these qualities, which eventually merge into the willingness, will and ability to build an independent new Uzbekistan. Being fundamental in the formation of a new young person, internationalist education not only does not remove the huge importance of moral, labor and legal education, as relatively independent links in the educational process, but also assumes that it is in the labor sphere and the sphere of moral consciousness and human behavior that the ideological and political qualities of the individual are tested, strengthened and acquire additional strength.

In labor education, first of all, it is the education of a deep understanding by every young person of the role of labor in our society, of their place in the labor process, in ensuring highly effective activities in the interests of the collective, the entire multinational society.

Secondly, labor education is designed to give a correct idea of the importance of public property as the basis of the economic system of the new Uzbekistan, the belief in the need to protect and increase the national wealth.
Third, in the conditions of Uzbekistan, the most important direction is the education of civic duty, active participation in the management of production, the affairs of society.

In the socio-demographic division of society, they overlap in a certain way, forming a complex, multidimensional social structure of society. It is supplemented by a system of interethnic relations, professional division of labor, etc. From the point of view of the organization of educational work, it is important to take into account the differences between the city and the village, large, medium and small cities, working-class settlements, separated settlements, isolated groups of young people employed in industry, but also living in rural areas or suburbs.

Internationalist education not only occupies an exceptionally important place in the integrated approach to spiritual and moral education, but even without it, the integrated approach itself is unthinkable $[17,18]$. A special place in the formation of the internationalist maturity of the object is occupied by the issues of language: national, native language, language of interethnic communication and other languages of peoples in general. This is done through language. Without the knowledge of languages, it is impossible to communicate within national and interethnic relations. Assessing the social significance of the language in the life of peoples. Stuchka even wrote that " the national question is primarily a question of language"[6].

Language is a means of the people and their life activity, and their relations with other peoples, a means in the implementation of the goals and objectives of the people. From the point of view of the formation of internationalist maturity, there are no "small", 
"unimportant", "secondary" and "primary" languages. In this, all languages are necessary, important, and valuable. Another question is about the role and significance of other languages, especially the language of internationalist communication, in the education of internationalism and friendship of peoples.

The level of knowledge of other peoples ' languages, especially the language of interethnic communication-Russian-is relatively high.

\section{Uzbek national mentality and its features.}

Each nation has a special, unique mentality. The mentality is formed in the course of the social, economic, political and ethno-cultural life of the people who have reached the level of the nation, as a set of socio-psychological state of its positive and negative properties and character, within the original historical, ethno-cultural and natural-climatic conditions. National identity is formed on the basis of socio-economic and political processes, mutual ethno-cultural relations over a long historical period $[5,8,13]$.

Internationalist maturity includes a number of mutually reinforcing components: a) knowledge of the national theory, the basic principles of internationalism; b) belief in their great rightness, justice, humanity; c) understanding of their responsibility for their implementation; d) active participation in the actual implementation of the Uzbek national policy - Independent Uzbekistan.

The essential orientation of the education of internationalist maturity of students, the formation of appropriate ideological, ideological and moral values, feelings and emotions, political and volitional qualities is realized primarily in the family - the primary social unit of society.

The first President of Uzbekistan, I. A. Karimov, reflecting on the prospects of independence and the ways of its development, said that the Uzbek people have deeply realized their true history, having made their property the priceless heritage left by our great ancestors, have learned to measure their prospects with the standards of our great history, clearly and broadly see their future; the Uzbek nation, which had endured oppression for centuries, remained fragmented and fragile, began to form as a single, monolithic nation, and truly acquired the feelings of national pride and selfconsciousness inherent in a great and free people [2].

The first President of the country is absolutely right, because the peculiar national mentality is characterized by versatility and inviolability.

Another important quality of the Uzbek national mentality is that the life of society, the way of life of people in many cases is managed through traditions and customs $[6,14,15]$. For example, in those Uzbek families where customs and traditions are strictly adhered to, special understanding is required from parents and relatives when marrying a son, choosing a bride, marrying daughters, choosing a groom. First of all, the health of the future bride and groom, their lack of physical disabilities, social origin, social status, authority and reputation of matchmakers in society are taken into account. The desire of parents to find a worthy couple for their children, not to make a mistake in this regard, is based on the collective opinion and public opinion [1].

President I. A. Karimov gives this assessment of this quality, which is characteristic of the 
Uzbek mentality: Here in Central Asia, we have historically lived in communities all our lives. In some Western countries, individualism is highly developed. It is not acceptable for our Republic. Say mahalla. In Uzbekistan, the mahalla institute is very strong. And when I talk about specifics, I mean that if individualism prevails in American democracy, then we are used to living with somewhat different norms, that is, the interests of society [2].

The future of our nation is directly linked to the confidence of our young people in the future, their professionalism, knowledge and qualifications.

Our country has developed a " National Training Program", one of the tasks outlined in the Program was to implement fundamental reforms in the education system, which led to the adoption of the Law "On Education".

At present, both of these state documents, which have historical significance, serve as the basis for educating young people who possess general, special knowledge, who have formed a modern worldview, national and universal values.

Among the students there are young men and women who are well versed in the theory of internationalism, who know the works of the classics, the documents of the Oliy Majlis on the national question. They are usually able to pass the test exams on these problems perfectly.

Noted in the materials of the Address of President Sh. M. Mirziyoyev "The whole atmosphere of our life and joint work - the family, preschool institutions and schools, the army, culture, literature, art-is designed to form and educate Uzbek people of all nationalities, and especially young people, the most favorable feelings - feelings of internationalism and patriotism"[7].

All the young people who are studying should become truly internationalist, and every schoolboy and student should become mature. But every young person should also be prepared to solve the problems of internationalist education in the family, labor collectives, mahallas, in society, in general, because today's student or student, tomorrow's parent, a member of a multinational collective, its leader and educator.

Internationalist education is recognized to solve two main functions: creative-creative, i.e. to form positive, positive qualities of the internationalist, to form and the individual, collective, community of people full internationalist maturity and - "protectivedestructive" function, i.e., the function of the struggle with all the antipodes of justice of the Law. Of course, only an internationalist mature young man can successfully fight.

In the spiritual life of the Uzbek people, the educational role of Islam and its outstanding figures is significant. Accordingly, Tashkent has established not only a higher educational institution, an Islamic university, but also a center of Islamic civilization, international research centers named after Imam Bukhari and Imam Termizi, an Islamic Academy, where students study on the basis of primary sources of Muslim law, Sufism, and Jajs, which are stored in the manuscript collections of the Republic. They contain the true humanistic essence of Islam, which calls all people, regardless of their nationality, religion and social status, to goodness, mercy and harmony. 
Currently, tourism is one of the promising industries that bring high income to the national economy. Uzbekistan is a country with a huge tourist potential. There are 7,3 thousand cultural heritage sites, a significant part of which is included in the corresponding UNESCO list.

In accordance with the adopted Strategy of Action of the Republic of Uzbekistan, it consistently continues the policy of comprehensive development of friendly and mutually beneficial relations with all countries of the far and near abroad, primarily with neighboring states, as well as with international organizations.

"I am convinced," said the President of the Republic of Uzbekistan, Sh. M. Mirziyoyev , " that by remaining true to ourselves, not engaging in self-deception, working honestly and conscientiously, we will definitely reach all the frontiers to which we strive"[4].

All this raises the authority of the multinational collective, promotes the development of public self-government.

In modern conditions, Uzbekistan sets the task of raising the role of leadership personnel for the state of internationalist and patriotic educational work.

The educational impact of the leader on young people is diverse. From the whole variety of forms of influence, we single out the most important ones. First, word education. This means that the manager must have the basic skills of an agitator, propagandist, that is, be an ideological worker: secondly, education by deed, that is, the manager must be well versed in technical and economic issues, be an organizer, be able to set the production process so that it contributes to the unity of a multinational team, creating conditions for creative work for everyone and bringing joy to everyone; thirdly, education by personal example, and this is especially important since the actions of the manager are perceived as the norm of behavior.

The fifth direction-ensuring security, interethnic harmony and religious tolerance, as well as the implementation of a balanced, mutually beneficial, constructive foreign policy-provides for the implementation of measures to protect the constitutional order, the sovereignty of the territorial integrity of the Republic, as well as the development of a concept of state policy in the field of interethnic relations and in the religious sphere.

The implementation of the action strategies will be a powerful impetus for the reform of the country, building a legal, democratic state and a strong civil society, ensuring interethnic harmony and religious tolerance in the society, as well as filling it with faith in the future, giving new strength to the representatives of the creative intelligentsia.

In recent years, the civic activity of the people has significantly increased, people are not afraid to express their opinions. The psychological climate in which we live and work has become different. However, all this is clearly not enough, there are still many problems waiting to be solved. First of all, this concerns the ideological support of issues of interethnic relations. We hold inter-state festivals, which would be much more useful, for example, for the friendship festivals of peoples living in the same city, region or, best of all, mahalla. Such a festival would help to revive the lost national identity, and at the same time it would be a tribute to all the nationalities living in a particular locality. Holding such events will better help the disclosure of self-made talents, the revival of 
national crafts, identity and originality in the design of the home.

\section{REFERENCES}

1. Askarov Axmadali (2018). Istoriya proisxojdeniya uzbeksogo naroda.

2. Karimov I.A. (1996). Po puti sozidaniya.

3. Xalimbetov Yu.M. (2004). Milliy mentalitetimiz istiqbolimiz tayanchi. O'zbek xalqining kelib chiqishi. Ilmiy, metodik yondoshuvlar etnogenistik va etnik tarix" mavzusidagi Respublika ilmiy - nazariy seminar materiallari, 57.

4. Poslaniye Prezidenta Respubliki Uzbekistan Sh.M. Mirziyoyeva Oliy Majlisu (2017). "Pravda Vostoka", 4.

5. Ashirov A. (2004). Uzbek milliy mentaliteti xaqida ba'zi mulohazalar. O'zbek xalqining kelib chiqishi. Ilmiy metodologik yondoshuvlar, etnogenetik va etnik tarix, 55 .

6. Stuchka P. I. (1994). Natsionalniy vopros i latishskiy proletariat, 2, 43.

7. Poslaniye Prezidenta Respubliki Uzbekistan Sh.M. Mirziyoyeva Oliy Majlisu (2020). "Zarafshon", 2.

8. Bekmurodov M. O’zbek mentaliteti. Kecha va bugun. "Tafakkur"

9. Xalimbetov Yu.M. (2018). Uzbeksiy natsionalniy mentalitet i yego osobennosti. Istoriya proisxojdeniya uzbekskogo naroda, 543.

10. Xalimbetov Yu.M. (1987). Iz opita internatsionalistskogo vospitaniya $v$ vuzax Respublik Sredney Azii. Aktualniye problemi formirovaniya internatsionalistskoy zrelosti uchaщyeysya molodeji, 65 .

11. Guboglo M.N. (1987). O razrabotke nauchnoy osnovi voprosov internatsionalnogo vospitaniya. Tezisi dokladov i soobщyeniy respublikanskoy nauchnoprakticheskoy konferensii, 13-14.

12. Xalimbetov Yu.M. (1989). Kulturniye traditsii i problemi garmonizatsii mejnatsionalnix otnosheniy (na primere Respublik Sredney Azii i Kazaxstana). Tezisi dokladov Respublikanskoy nauchnoprakticheskoy konferensii. Mejnatsionalniye otnosheniya i internatsionalnoye vospitaniye molodeji: problemi, poiski, resheniya.

13. Sobirovna, T. R. (2021). Issues of further improvement of water cadastre legislation of Uzbekistan. ACADEMICIA: An International Multidisciplinary Research Journal, 11(4), 1241-1253.

14. Askarov A. (2007). Uzbek xalkning etnogenezi va etnik tarixi, 59-60.

15. Shoniyozov K. (1974). K etnicheskoy istorii uzbekskogo naroda.

16. Erkayev A. (2011). Uzbekiston yuli.

17. Ermatov M.(1968). Etnogenez i formirovaniye uzbekskogo naroda.

18. Etnicheskiy atlas Uzbekistana (2002).

19. Brolish Ya.S. (1969). Internatsionalistskoye vospitaniye zakonomernost stanovleniya i razvitiya obraza jizni.

20. Gurov Yu.S. (1974). Organizatsiya individualnoy raboti s molodyojyu.

21. Ponomarev A.l. (1969). Bez etogo ne oboytis. Molodoy kommunist, 11. 